\title{
GADAI EMAS SYARIAH: EVALUASI DAN USULAN AKAD SESUAI PRINSIP SYARIAH
}

\author{
Putri Dona Balgis \\ Universitas Padjajaran \\ putridonabalgis@gmail.com
}

\begin{abstract}
Abstrak
$\mathrm{P}$ roduk-produk dalam perbankan syariah terus mengalami perkembangan, salah satunya adalah gadai emas syariah. Praktik gadai emas pada bank syariah menggunakan kombinasi dari tiga akad yakni qard, rahn dan ijarah. Penelitian ini mendeskripsikan penerapan gadai emas pada perbankan syariah di Indonesia, meninjau prinsip syariah yang terkandung di dalamnya, dan menawarkan kombinasi akad yang sesuai dengan prinsip syariah, pertama kombinasi akad rahn dan ijarah, kedua menggunakan akad musyarakah mutanaqisa. Dari hasil penelitian ditemukan bahwa masih terdapat praktik gadai emas di bank syariah yang tidak sesuai dengan ketentuan syariah.
\end{abstract}

Kata Kunci: gadai emas, bank syariah, prinsip syariah

\begin{abstract}
$P$ roducts in Islamic banking continuosly face developments, one of which is a sharia gold pawn. The practice of gold pawn in Islamic banks use combination of the three contracts: Qard, Rahn and Ijara. This study describes the application of gold pawn on Islamic banking in Indonesia, reviews sharia principles in it, and offers combination of contract in accordance with Islamic principles, the first combination is Rahn contract and Ijarah, Second is Musharaka mutanaqisa contract. The study reveals that gold pawn practices in Islamic banks are not in accordance with the adherence of sharia.
\end{abstract}

Keywords: pawn gold, Islamic bank, sharia principles

\section{Latar Belakang}

Perbankan syariah merupakan lembaga keuangan yang patuh dan berlandaskan pada prinsip-prinsip syariah. Adalah kewajiban perbankan memastikan bahwa setiap produk yang ditawarkan kepada masyarakat sudah sesuai dengan syariah. Dengan pesatnya perkembangan perbankan syariah saat ini, mau tidak mau mendorong perbankan syariah untuk melakukan pengembangan terhadap produk-produk yang ditawarkan.

Bank syariah memiliki perbedaan yang jelas dengan bank konvensional yang hanya memiliki tujuan materi. Disamping menjadi lembaga bisnis, bank syariah juga memiliki fungsi sosial yakni menjalankan fungsi sosial dalam bentuk lembaga baitul mal, yaitu menerima dana yang berasal dari zakat, infak, sedekah, hibah, atau dana sosial lainya dan menyalurkannya kepada organisasi pengelola zakat. Bank Syariah dan UUS dapat menghimpun dana sosial yang berasal dari dana wakaf uang dan menyalurkanya kepada pengelola wakaf (nadzir) sesuai dengan kehendak pemberi wakaf (wakif). ${ }^{169}$

Salah satu inovasi produk yang ditawarkan oleh perbankan syariah yang sempat menarik minat masyarakat luas adalah gadai emas syariah. Emas bagi masyarakat Indonesia merupakan pilihan investasi yang tak pernah terlupakan. Dengan adanya produk gadai emas pada bank syariah, seolah menjadi jawaban dari kebutuhan masyarakat. Bank Syariah Mandiri

169 Undang-Undang Nomor 21 tahun 2008 tentang perbankan syariah, pasal 4,ayat 2 dan 3 
membukukan nilai Rp. 1,77 triliun dalam lima bulan pertama di tahun 2016, meningkat 30 persen dibandingkan dengan periode tahun lalu Rp. 1,44 triliun. ${ }^{170}$

Menurut data dari Bank Indonesia, transaksi gadai emas syariah di industri perbankan syariah tumbuh hingga 15 persen sampai akhir semester 1- 2012. Hingga Juli 2012, total tranksaksi akad qardh pada perbankan syariah mencapai Rp 7,5 triliun atau 8,9 persen dari total pembiayaan yang diberikan sebesar 85 triliun. Sementara itu porsi bisnis gadai emas syariah berada pada kisaran tiga sampai enam persen dari total pinjaman. ${ }^{171}$

Tingginya minat masyarakat terhadap gadai emas syariah membuat perlu adanya kajian mengenai bagaimanakah praktik gadai emas syariah di bank syariah? Apakah sudah sesuai syariah? Jika belum bagaimana solusinya?

\section{Rumusan Masalah}

Yang menjadi rumusan masalah dalam penelitian ini adalah "bagaimana praktik gadai emas syariah di Indonesia khususnya pada perbankan syariah?" serta "bagaimana bentuk atau pola gadai emas syariah yang sesuai dengan syariah?"

\section{Hasil dan Pembahasan}

Gadai Syariah (Rahn) secara harfiah adalah tetap, kekal, dan jaminan. Secara istilah rahn adalah apa yang disebut dengan barang jaminan, agunan, cagar atau tanggungan. Rahn yaitu menahan barang sebagai jaminan atas utang. Akad rahn juga diartikan sebagai sebuah perjanjian pinjaman dengan jaminan atau dengan melakukan penahanan harta milik si peminjam sebagai jaminan atas pinjaman yang diterimanya. Barang gadai baru dapat diserahkan kembali pada pihak yang berhutang apabila utangnya sudah lulus. ${ }_{.}^{172}$

Akad rahn bertujuan agar pemberi pinjaman lebih memercayai pihak yang berhutang. Pemeliharaan dan penyimpanan barang gadaian hakekatnya adalah kewajiban pihak yang menggadaikan (rahin), namun dapat juga dilakukan oleh pihak yang menerima barang gadai (murtahin) dan biayanya harus ditanggung rahin. Besarnya biaya ini tidak boleh ditentukan berdasarkan jumlah pinjaman.

Apabila barang gadaian dapat diambil manfaatnya, misalnya mobil maka pihak yang menerima barang gadaian boleh memanfaatkannya atas seizin pihak yang menggadaikan dan sebaliknya ia berkewajiban memelihara barang gadaian.

Untuk barang gadaian berupa emas tidak ada biaya pemeliharaan, yang ada adalah biaya penyimpanan. Penentuan besarnya biaya penyimpanan dilakukan dengan akad ijarah.

Gadai emas syariah adalah penggadaian atau penyerahan hak penguasaan secara fisik atas harta atau barang (berupa emas) dari nasabah (ar-rahin) kepada bank (al-murtahin) untuk dikelola dengan prinsip Ar-rahn yaitu sebagai jaminan (al-marhun) atas peminjaman atau utang (al-mabunbiih) yang diberikan kepada nasabah atau peminjam tersebut. ${ }^{173}$

Pada saat jatuh tempo yang berutang berkewajiban untuk melunasi hutangnya. Apabila ia tidak dapat melunasinya maka barang gadaian dijual kemudian hasil penjualan bersih digunakan untuk melunasi utang dan biaya pemeliharaan yang terutang. Apabila ada kelebihan antara harga jual barang gadaian dengan besarnya utang maka selisihnya diserahkan kepada yang berutang tetapi apabila ada kekurangan maka yang berutang tetap harus membayar sisa utangnya tersebut.

Dalam rahn, barang gadaian tidak otomatis menjadi milik pihak yang menerima gadai

170 Elisa Valenta Sari, Gadai Emas Meningkat Bank Syariah Mandiri Bukukan Rp. 1,7 T, http://www.cnnindonesia.com/ekonomi/20160614192719-78-138160/gadai-emas-meningkat-bank-syariah-mandiri-bukukan-

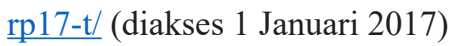

171 Statistik BI tahun 2012

172 Sri Nurhayati, Akuntansi Syariah di Indonesia Edisi Empat (Jakarta: Salemba Empat, 2015), 269

173 Heri Sudarsono, Bank dan Lembaga Keuangan Syariah: Deskripsi dan Ilustrasi (Yogyakarta: Ekonosia, 2003, Cet. 1 ), 164-165 
(pihak yang memberi pinjaman) sebagai pengganti piutangnya. Dengan kata lain fungsi rahn di tangan mutarhin (pemberi utang) hanya berfungsi sebagai jaminan utang dari rahin (orang yang berhutang). Namun barang gadaian tetap milik orang yang berutang.

Manfaat yang dapat diambil oleh bank dari prinsip ar-rahn adalah sebagai berikut: ${ }^{174}$

1. Menjaga kemungkinan nasabah untuk lalai atau bermain-main dengan fasilitas pembiayaan yang diberikan bank.

2. Memberikan keamanan bagi semua penabung dan pemegang deposito bahwa dananya tidak akan hilang begitu saja jika nasabah peminjam ingkar janji karena ada suatu aset atau barang (marhun) yang dipegang oleh bank.

3. Jika rahn diterapkan dalam mekanisme pegadaian, sudah barang tentu akan sangat membantu saudara kita yang kesulitan dana, terutama di daerah-daerah.

Adapun manfaat langsung yang didapat bank adalah biaya-biaya konkret yang harus dibayar oleh nasabah untuk pemeliharaan dan keamanan aset tersebut. Jika penahanan aset berdasarkan fidusia (penahanan baran bergerak sebagai jaminan pembayaran), nasabah juga harus membayar biaya asuransi yang besarnya sesuai dengan yang berlaku secara umum.

Ada empat fatwa yang berhubungan dengan gadai emas syariah:

1. Fatwa DSN Nomor: 26/DSN-MUI/III/2002 tentang Rahn Emas

2. Fatwa DSN Nomor: 25/DSN-MUI/III/2002 tentang Rahn

3. Fatwa DSN Nomor: 19/DSN-MUI/IV/2001 tentang Al-Qard

4. Fatwa DSN Nomor: 79/DSN-MUI/III/2011 tentang Qardh dengan Menggunakan Dana Nasabah

Dalam Fatwa DSN No. 19, disampaikan bahwa ketentuan umum al-qardh adalah sebagai berikut:

1. Al-Qardh adalah pinjaman yang diberikan kepada nasabah (muqtaridh) yang memerlukan.

2. Nasabah al-Qardh wajib mengembalikan jumlah pokok yang diterima pada waktu yang telah disepakati bersama.

3. Biaya administrasi dibebankan kepada nasabah.

4. LKS dapat meminta jaminan kepada nasabah bilamana dipandang perlu.

5. Nasabah al-Qardh dapat memberikan tambahan (sumbangan) dengan sukarela kepada LKS selama tidak diperjanjikan dalam akad.

6. Jika nasabah tidak dapat mengembalikan sebagian atau seluruh kewajibannya pada saat yang telah disepakati dan LKS telah memastikan ketidakmampuannya, LKS dapat:

a. memperpanjang jangka waktu pengembalian, atau

b. menghapus (write off) sebagian atau seluruh kewajibannya.

Dana al-Qardh dapat bersumber dari:

1. Bagian modal LKS;

2. Keuntungan LKS yang disisihkan; dan

3. Lembaga lain atau individu yang mempercayakan penyaluran infaqnya kepada LKS.

Perbankan syariah pada mulanya mengacu pada fatwa ini, qard beragunan emas. Karena memang tertulis bahwa LKS dapat meminta jaminan kepada nasabah bilamana dipandang perlu. Pengadaan jaminan atau agunan memberikan kemanan atau sebagai pengurang risiko bagi bank. Poin penting lainnya yang perlu diperhatikan adalah mengenai dari mana sumber dana qard berasal. Seperti apa yang tertulis pada paragraf sebelumnya, tak satupun dana berasal dari dana pihak ketiga dengan niat invesasi. Sehingga akad ini tidak akad berdampak (merugikan) bagi DPK.

174 Syafii Antonio, Bank Syariah Dari Teori ke Praktik (Jakarta: Gema Insani, 2001), 130 
Pada Fatwa DSN No. 26 tentang Rahn emas dinyatakan bahwa:

1. Rahn Emas dibolehkan berdasarkan prinsip Rahn (lihat Fatwa DSN nomor: 25/DSN-MUI/ III/2002 tentang Rahn).

2. Ongkos dan biaya penyimpanan barang (marhun) ditanggung oleh penggadai (rahin).

3. Ongkos sebagaimana dimaksud ayat 2 besarnya didasarkan pada pengeluaran yang nyatanyata diperlukan.

4. Biaya penyimpanan barang (marhun) dilakukan berdasarkan akad Ijarah.

Fatwa DSN Nomor 79 tentang Qard menggunakan dana nasabah, ketentuan penyaluran dana qardh dengan dana nasabah adalah sebagai berikut:

1. Akad Qardh dalam Lembaga Keuangan Syariah terdiri atas dua macam:

a. Akad Qardh yang berdiri sendiri untuk tujuan sosial semata sebagaimana dimaksud dalam Fatwa DSN-MUI Nomor: 19/DSN-MUI/IV/2001 tentang al-Qardh, bukan sebagai sarana atau kelengkapan bagi transaksi lain dalam produk yang bertujuan untuk mendapatkan keuntungan;

b. Akad Qardh yang dilakukan sebagai sarana atau kelengkapan bagi transaksi lain yang menggunakan akad-akad mu'awadhah (pertukaran dan dapat bersifat komersial) dalam produk yang bertujuan untuk mendapatkan keuntungan.

2. Akad atau produk yang menggunakan akad qardh sebagai sarana atau kelengkapan bagi akad mu'awadhah sebagaimana dimaksud pada angka 1.b di atas, termaktub antara lain dalam:

a. Fatwa DSN-MUI Nomor: 26/DSN-MUI/III/2002 tentang Rahn Emas;

b. Fatwa DSN-MUI Nomor: 29/DSN-MUI/VI/2002 tentang Pembiayaan Pengurusan Haji Lembaga Keuangan Syariah;

c. Fatwa DSN-MUI Nomor 31 tentang Pengalihan Utang;

d. Fatwa DSN MUI Nomor: 42/DSN-MUI/V/2004 tentang Syariah Charge Card;

e. Fatwa DSN MUI Nomor: 54/DSN-MUI/X/2006 tentang Syariah Card;

f. Fatwa DSN MUI Nomor: 67/DSN-MUI/III/2008 tentang Anjak Piutang Syariah.

3. Akad Qardh sebagaimana dimaksud dalam angka 1.a tidak boleh menggunakan dana nasabah.

4. Akad Qardh sebagaimana dimaksud dalam angka 1.b boleh menggunakan dana nasabah.

5. Keuntungan atau pendapatan dari akad atau produk yang menggunakan mu'awadhah yang dilengkapi dengan akad qardh sebagaimana dimaksud dalam angka 2 harus dibagikan kepada nasabah penyimpan dana sesuai akad yang dilakukan.

Fatwa DSN Nomor 79 ini ditetapkan pada tahun 2011, sembilan tahun setelah fatwa DSN Nomor 26 tentang Rahn emas digunakan. Pada fatwa DSN No. 26 tidak terdapat ketetapan mengenai penggunaan akad Qard dalam kontrak Rahn emas, namun pada fatwa DSN Nomor 79 terdapat ketetapan penggunaan akad Qard dalam kontrak Rahn emas (Poin 2.a). Sehingga terjadi kombinasi akad pada Rahn emas, yakni Rahn, Qard, dan Ijarah.

Tidak ada definisi mengenai kombinasi akad pada literatur fikih. Namun demikian, kombinasi akad (ijtima al-Uqud) dapat didefinisikan sebagai suatu perjanjian antara dua pihak atau lebih untuk menempatkan secara bersama-sama dua atau lebih kontrak dengan fitur dan konsekuensi hukum yang berbeda untuk mencapai transaksi yang layak diinginkan. Dalam hal ini, semua kewajiban dan konsekuensi hukum yang timbul dari kontrak gabungan yang akan direalisasikan sebagai satu kewajiban tunggal. ${ }^{175}$

Perkembangan yang mengesankan dari perbankan dan industri keuangan Islam dari hari ke hari harus menyediakan produk dan layanan kompetitif untuk memenuhi kebutuhan bisnis saat

175 Hammad, Ijtima' al-uqud al-Muta'didah fi Safaqah Wahida fi al-Fiqh al-Islami. A'mal al-Nadwah al-Fiqhiyyah al-Khamisa (Kuwait: Kuwait Finance House, 1998), hal. 511 
ini dan perdagangan terutama di era transaksi elektronik. Itu berarti kontrak yang digunakan dalam perbankan syariah lebih rumit dari yang sebelumnya dan menyiratkan bahwa produk dan layanan baru di bidang keuangan Islam akan menggunakan lebih dari satu kontrak dalam satu transaksi. Beberapa peneliti seperti Al-Shadhily (1998); Abu Guddah (2000); Arbouna (2007); dan Dusuki (2009) telah meneliti konsep kontrak hybrid di bidang keuangan Islam dan aplikasinya untuk tujuan pengembangan produk di bidang perbankan dan keuangan Islam. ${ }^{176}$

Namun, kontrak hybrid adalah isu kontroversial di bidang keuangan Islam karena hadits yang melarang "dua kontrak dalam satu transaksi". Interpretasi yang salah dari hadits berpotensi mengalahkan setiap upaya untuk memungkinkan penggabungan kontrak di bidang keuangan Islam terlepas dari sifat dan fitur dari kontrak gabungan dan menghambat pengembangan produk di perbankan syariah. Namun demikian, secara syariah transaksi dapat terdiri lebih dari satu kontrak dan itu adalah halal, kombinasi tersebut harus mengikuti pedoman dan parameter Syariah. ${ }^{177}$

Memang, ada empat hadis Nabi saw sehubungan dengan larangan kontrak hybrid dalam transaksi bisnis. Keempat hadis berisi empat pembatasan, larangan pertama adalah kombinasi antara bai' (penjualan) dan salaf (pinjaman) yang diriwayatkan oleh Malik, yang kedua adalah larangan bai' ataini Fi bai' ah (dua kontrak dalam satu transaksi atau dua penjualan dalam satu transaksi), larangan ketiga adalah dari shafqataini fi shafqah (dua transaksi dalam satu transaksi), dan larangan keempat adalah bai' wa shart (dijual dengan kondisi). Keempat hadits selalu digunakan sebagai referensi yang salah oleh mayoritas stakeholder perbankan syariah di Indonesia dengan melarang kontrak hybrid pada umumnya untuk mengembangkan akad di setiap produk dan layanan perbankan syariah. ${ }^{178}$

Ibn Qayyim berpendapat bahwa Nabi saw melarang kontrak hybrid antara kontrak penjualan dan pinjaman (qardh), meskipun setiap kontrak berdiri secara individual atau terpisah. Larangan menggabungkan kontrak salaf (kontrak pinjaman) dan penjualan dalam kontrak adalah untuk menghindari riba. Kombinasi kontrak ini dilarang karena jika seseorang meminjamkan Rp. 1000 kepada temannya, lalu dia menjual barang senilai Rp. 800 dengan uang Rp. 1000 tadi untuk mendapatkan bayaran tambahan dua ratus dari transaksi tersebut. Dalam transaksi ini ia menerima surplus dua ratus dalam transaksi kedua, meskipun tampak seperti dia memberikan pinjaman tanpa biaya tambahan dalam kontrak pertama. Mayoritas ulama Muslim sepakat untuk melarang kombinasi penjualan dengan kontrak pinjaman dalam satu transaksi. Argumen ini diperkuat oleh Hammad, di mana ia berpendapat bahwa setiap produk di bidang perbankan dan keuangan Islam terstruktur atas dasar kontrak hybrid tidak dapat diterima dalam hukum Islam karena itu bertentangan dengan sumber eksplisit. Sebagai contoh, adalah melanggar hukum Syariah ketika mengucurkan fasilitas pinjaman untuk bank syariah dan pada saat yang sama, pelanggan menjual aset tertentu ke bank syariah. Transaksi ini berada di bawah kategori menggabungkan kontrak pinjaman dengan penjualan untuk memperoleh keuntungan. ${ }^{179}$

Isu lain dalam penggabungan kontrak yang secara tegas dilarang oleh hadits ini menggabungkan dua kontrak penjualan dalam transaksi (bai' tayn fi bai' ah). Mayoritas ulama Muslim sepakat bahwa setiap produk yang terstruktur atas dasar kombinasi kontrak yang dimaksudkan untuk menghindari transaksi haram seperti riba, gharar, dan maysir tidak dapat diterima. Dengan kata lain, hal ini berarti kombinasi antara kontrak ijarah dengan pinjaman

176 "Hybrid Contract in Islamic Banking and Finance: A Proposed Shariah Principles and Parameters for Product Development", European Journal of Business and Management-Special Issue: Islamic Management and Business, (Vol. 7, No. 16, 2015), 89

177 "A Possible Mechannism for Product Development in Islamic Banking and Finance", Thunderbird International Business Review (Vol. 49, No. 3, May-June 2007), 342

178 "Hybrid Contract in Islamic Banking and Finance: A Proposed Shariah Principles and Parameters for Product Development", European Journal of Business and Management-Special Issue: Islamic Management and Business, (Vol. 7, No. 16, 2015), 92

179 Ibid. hal. 94 
dalam produk rahn di bank syariah di Indonesia dalam rangka untuk mendapatkan keuntungan dari kontrak pinjaman dalam nama ijarah dan kombinasi penjualan dan kesepakatan pembelian kembali dalam produk pembiayaan ba'I al-inah untuk mendapatkan keuntungan dari penjualan yang tidak diinginkan adalah tidak diperbolehkan. Dalam ba'i al-inah, ada kombinasi dari kontrak antara pembayaran ditangguhkan dengan pembayaran tunai yang mengarah ke riba. Biasanya, seseorang yang menjual sesuatu dengan kredit, dengan syarat bahwa pembeli akan menjualnya kembali secara tunai dengan harga yang lebih rendah. transaksi semacam ini bagaimanapun juga adalah Hilah atau manipulasi untuk melegalkan riba, di mana pada kenyataannya tidak ada transaksi yang sebenarnya dilakukan dalam kontrak.

AAOIFI (No. 25/2008) menetapkan empat pembatasan Syariah pada penggabungan kontrak, penggabungan kontrak pertama yang telah dikutip untuk menggabungkan penjualan dengan pinjaman, atau menggabungkan dua penjualan dalam satu kesepakatan, atau dua transaksi dalam satu transaksi. Kedua, dilarang untuk menggabungkan kontrak sebagai trik untuk mempraktekkan riba, berdasarkan atas petunjuk Nabi saw yang menunjukkan larangan ba'i al-inah dan riba fadhl. ketiga, itu adalah larangan untuk menggunakan kombinasi dari kontrak sebagai alasan untuk melakukan transaksi riba, berdasarkan hadits Nabi yang melarang menggabungkan pinjaman dengan penjualan. Keempat, kombinasi dari kontrak tidak boleh bertentangan satu sama lain dalam hal tujuan atau aturan Syariah.

AAOIFI tahun 2007 dan 2008 telah memberikan resolusi No. 25 yang mengatakan bahwa seluruh perjanjian kontrak hibrid diperbolehkan asalkan kontrak harus dipisahkan satu sama lain dan setiap kontrak diperbolehkan sendiri, kecuali kombinasi kontrak penjualan dan pinjaman. AAOIFI kemudian membuat peraturan dan parameter Syariah kontrak hybrid dengan aturan berikut:

1. Kombinasi dari kesepakatan kontrak tidak menggabungkan dengan kontrak yang telah jelas dilarang dalam syariah seperti kombinasi antara penjualan dan pinjaman dalam satu transaksi.

2. Kombinasi dari kesepakatan kontrak tidak dapat digunakan sebagai trik (Hilah) untuk membenarkan riba. Seperti kontrak penjualan dan pembelian kembali kesepakatan antara dua pihak (bay' al-inah) atau fadl riba.

3. Kombinasi dari kesepakatan kontrak tidak dapat digunakan sebagai alat untuk riba seperti kreditur meminjamkan uang untuk mendapatkan hadiah dari debitur atau memberikan manfaat lain seperti memberikan tumpangan atau menawarkan akomodasi di rumahnya.

4. Kombinasi kesepakatan kontrak tidak harus bertentangan dengan esensi kontrak. Misalnya, seperti dalam kontrak mudharabah, seharusnya tidak ada jaminan keuntungan menggunakan perjanjian hibah di tempat pertama atau kombinasi antara pertukaran mata uang dengan kontrak Ju'alah, atau bay' al-salam dengan ju'alah.

Dari paparan di atas dapat disimpulkan bahwa kombinasi akad antara akad penjualan dan akad pinjaman seperti kombinasi akad qard dan ijarah, akad qard dan murabahah, akad qard dan salam dan akad penjualan lainnya.

Bank Umum Syariah (BUS) yang ada di Indonesia saat ini berjumlah 13, setelah bulan September 2016 lalu, Bank Aceh melakukan konversi dari bank konvensional menjadi bank umum syariah.

Berdasarkan pengamatan penulis melalui website setiap BUS (penelurusan tanggal 29 Desember 2016), BUS yang memiliki produk Rahn emas adalah sebagai berikut:

1. Bank Syariah Mandiri

2. BRI Syariah

3. BPTN Syariah

4. BJB Syariah

5. Bank Syariah Bukopin 


\section{Bank Aceh}

Praktik Rahn emas di Indonesia menggunakan tiga akad, yakni akad Rahn, akad Qard untuk pinjaman dan akad ijarah untuk penyewaan Safe Deposit Box. Dalam Fatwa No.26 tentang Rahn emas ditetapkan bahwa ongkos dan biaya penyimpanan barang (marhun) ditanggung oleh penggadai (rahin), dimana ongkos dan biaya tersebut besarnya didasarkan pada pengeluaran yang nyata-nyata diperlukan. Dari kalimat tersebut dapat kita tarik kesimpulan bahwa ongkos dan biaya penyimpanan gadai tersebut tidak boleh menghasilkan tambahan keutungan bagi LKS, karena hanya biaya yang nyata-nyata diperlukan yang dibebankan pada penggadai (rahin).

Pada bank syariah di Indonesia, terdapat beberapa keganjilan dalam praktek Rahn emas. Pertama, penggabungan akad antara akad Qard dan akad Ijarah. Kombinasi kedua akad ini terlarang, karena sesuai dengan hadits Rasulullah. Kombinasi antara akad Qard yang merupakan akad pinjaman, yang mana tidak boleh mendapatkan tambahan atau kelebihan atau manfaat dari pinjaman digabungkan dengan akad ijarah yang merupakan akad jual beli jasa yang nyatanyata membebankan ujroh bagi nasabah. Dalam fatwa DSN No. 26 dinyatakan bahwa biaya yang dikeluarkan hanya biaya yang nyata-nyata diperlukan, hal ini bisa jadi merupakan trik (hillah) dari praktek riba atau menjadi jalan tengah dari penggabungan akad yang dilarang ini.

Kedua, akad ijarah yang dipraktikan pada perbankan syariah terbukti mengambil manfaat dari akad ini, bukan hanya biaya yang nyata-nyata diperlukan. Apakah benar bank syariah tidak mengambil untung dari penyewaan Safe Deposit Box(SDB)? Yang terjadi dalam akad qard dengan menggadaikan emas yang digabung dengan penyewaan emas gadai demi keamanan bahwa bank-bank syariah membebakan biaya yang bervariasi mulai dari Rp. 225.000 hingga Rp.750.000 per tahun untuk emas gadai seberat 25 gram. Padahal biaya sebanyak itu dapat menyewa SDB mulai dari ukuran kecil hngga besar yang mampu menampung ratusan emas batang 25 gram. Dan lebih menggenaskan lagi, pada saat penggadai emas menggadaikan emasnya untuk kedua kalinya, ia dibebankan lagi biaya sebesar biaya penyewaan sebauah SDB, padahal SDB yang dibayarnya pada gadai pertama masih mampu menampung ratusan emas batanng 25 gram. ${ }^{180}$

Sistem perhitungan ujroh yang ditetapkan oleh bank syariah berdasarkan jumlah hari bervariasi, ada yang mengenakan ujroh per hari, ada yang per sepuluh hari, ada yang per lima hari, ada yang per bulan. Sebaiknya penerapan ujroh dihitung per hari. Jika dihitung per lima belas hari maka berpotensi bank syariah mengambil untung lebih dari hari yang tersisa dari jatuh tempo pelunasan gadai. Jumlah perhitungan ujroh tidak boleh dikaitkan dengan besarnya pinjaman. Dari hal ini juga terlihat bahwa bank syariah mengambil kelebihan manfaat bukan hanya biaya yang nyata-nyata diperlukan.

Ketiga, bank syaiah berlomba-lomba dalam melakukan pinjaman menggunakan Rahn emas. Hal ini sangat terlihat saat sebelum BI mengeluarkan peraturan tentang pembatasan gadai emas pada bank syariah. Setelah itu, BI membatas porsi gadai emas syariah pada bank syariah maksimal 10\% dari total pembiayaan. Dana qard merupakan dana yang tidak meberian tambahan nilai atau fee bagi ank syariah. Qard merupakan salah satu instrumen sosial bank syariah, yang dananya berasal dari bagian modal LKS, keuntungan LKS yang disisihkan dan lembaga lain atau individu yang mempercayakan penyaluran infaqnya kepada LKS. Selain dana qard hakikatnya tidak memberikan keuntungan bisnis secara material kepada bank syariah, gadai emas juga memiliki banyak risiko terutama karena pergerakkan harga emas.

Setidaknya terdapat lima resiko yang dihadapi bank syariah dalam menjalankan gadai emas yaitu Market risk, penurunan harga emas yang menyebabkan turunnya investment return pemilik emas. Liquidity risk, sulitnya menjual emas di saat harganya turun. Lalu Capital risk: kerugian karena penurunan harga emas dapat menambah kerugian bank dan berpotensi menurunkan CAR.

180 Erwandi Tarizi, Harta Haram Muamalat Kontemporer (Bogor: Penerbit Berkah Mulia Insani Publishing,2013), 419 
Credit risk, penurunan harga emas berpotensi menunda ditebusnya kembali emas oleh client. Reputation risk, maraknya qardh untuk rahn emas dan berkebun emas berpotensi menurunkan fungsi dan peran utama bank syariah dalam membiayai usaha produktif di sektor riil. ${ }^{181}$

Perkembangan bank syariah yang semakin baik, memberikan pengaruh kepada pengembangan produk perbankan yang kompetitif, sehingga melakukan kombinasi akad bisa menjadi salah satu cara dalam pengembangan produk perbankan syariah yang mampu menjawab keinginan masyarakat.

Beberapa hasil pemikiran penulis terkait kombinasi akad untuk gadai emas syariah di perbankan syariah adalah sebagai berikut:

1. Akad qard diganti dengan akad jual beli seperti murabahah, salam, dan akad jual beli lainnya. Kombinasi ini tidak dapat diterapkan untuk rahn emas, karena tujuan awal akadnya adalah gadai bukan jual beli emas. Sehingga penggantian akad qard menjadi akad jual beli tidak dapat dilakukan. Kombinasi akad ini tidak sesuai tujuan.

2. Tetap menggunakan akad qard namun semua fee ijarah (ujroh) dicacat ke dalam dana kebajikan tidak dicatat sebagai pendapatan bank. Jika hal ini dilakukan, maka tidak cocok untuk bank sebagai lembaga bisnis. Bank tidak hanya kehilangan fee namun juga akan mendapatkan rugi karena senyatanya bank mengeluarkan biaya untuk penyimpanan barang gadai (marhun).

3. Tetap menggunakan akad qard namun tidak menngunakan akad ijarah. Konsepnya barang yang djaminnkan tetap disimpan bank, namun bank tidak menanggung risiko jika terjadi hal yang tidak diinginkan. Bank tetap mealakukan penyimpanan barang gadai dengan prinsip amanah. Sesuai fatwa DSN No. 19 tentang Qard menyatkan pada bagian pertama nomor 5, nasabah Al-Qard dapat memberikan tambahan (sumbangan) dengan sukarela kepada LKS selama tidak dipperjanjikan dalam akad. Sehingga bank tetap bisa mendapatkan fee dari pemberian pinjaman Qard. Hal ini sama saja dengan penggabungan akad qard dan ijarah, karena merupakah trik (hilah) dari praktik riba.

4. Tidak perlu menggunakan akad qard cukup rahn dan ijarah. Sama halnya dengan apa yang difatwakan dalam fatwa DSN No. 26 tentang Rahn emas, cukup menggunakan akad rahn sebagaimana fungsinya. Karena dengan akad Rahn, rahin mendapatkan pinjaman kemudian memberikan barang jaminannya. Barang jaminan tersebut dikenakan akad ijarah. Kombinasi akad rahn dan ijarah dibolehkan oleh syariah. Sehingga tidak berseberangan dengan aturan syariah dan tetap memberikan keuntungan bagi bank syariah selaku lembaga bisnis.

5. Menggunakan akad musyarakah mutanaqisa. Musyarakah mutanaqishah merupakan akad turunan dari musyarakah dan prosedurnya pun hampir sama dengan akad ijarah muntahia bittamlik. Musyarakah mutanaqishah (diminishing partnership) adalah bentuk kerjasama antara dua pihak atau lebih untuk kepemilikan suatu barang atau asset. Dimana kerjasama ini akan mengurangi hak kepemilikan salah satu pihak sementara pihak yang lain bertambah hak kepemilikannya. Perpindahan kepemilikan ini melalui mekanisme pembayaran atas hak kepemilikan yang lain. Bentuk kerjasama ini berakhir dengan pengalihan hak salah satu pihak kepada pihak lain. Dari definisi pemahaman tersebut, konsep akad musyarakah mutanaqishah dijadikan sebuah konsep dalam pembiayaan perbankan syariah, yaitu kerjasama antara bank syariah dengan nasabah untuk pengadaan atau pembelian suatu barang yang mana asset barang tersebut jadi milik bersama. Adapun besaran kepemilikan dapat ditentukan sesuai dengan sejumlah modal atau dana yang disertakan dalam kontrak kerjasama tersebut. Selanjutnya pihak nasabah akan membayar (mengangsur) sejumlah modal atau dana yang dimiliki oleh bank syariah. Jumlah modal bank syariah semakin

181 Mulya Siregar, Mencermati Rahn Emas pada Bank Syariah, http://zonaekis.com/mencermati-rahn-emas-pada-bank-syariah/ (diakses pada 30 Desember 2016) 
lama semakin kecil, berbanding terbalik dengan jumlah modal nasabah yang semakin bertambah karena pembayaran angsuran pada setiap bulan. Pada akhir masa pembiayaan, jumlah modal bank telah diambil alih 100\% oleh nasabah sehingga kepemilikan atas rumah (contoh-pen.) dialihkan menjadi atas nama nasabah. ${ }^{182}$

Perpindahan kepemilikan dari porsi bank syariah kepada nasabah seiring dengan bertambahnya jumlah modal nasabah dari pertambahan angsuran setiap bulannya. Apabila masa angsuran berakhir, berarti kepemilikan suatu barang atau benda tersebut sepenuhnya menjadi milik nasabah. Penurunan porsi kepemilikan bank syariah terhadap barang atau benda berkurang secara proporsional sesuai dengan besarnya angsuran. Selain sejumlah angsuran yang harus dilakukan nasabah untuk mengambil alih kepemilikan, nasabah harus membayar sejumlah sewa kepada bank syariah hingga berakhirnya batas kepemilikan bank syariah.Pembayaran sewa dilakukan bersamaan dengan pembayaran angsuran. Pembayaran angsuran merupakan bentuk pengambilalihan porsi kepemilikan bank syariah. Sedangkan pembayaran sewa adalah bentuk keuntungan (fee) bagi bank syariah atas kepemilikannya terhadap aset tersebut.Pembayaran sewa sekaligus merupakan bentuk kompensasi kepemilikan dan kompensasi jasa bank syariah.

Jika salah satu pihak gagal menyediakan sebagian modal yang diperjanjikan berdasarkan waktu yang telah disepakati dalam kontrak, maka pihak non-default boleh: ${ }^{183}$

1. Merevisi kontrak MMQ berdasarkan modal yang secara nyata telah dibayarkan oleh pihak yang gagal;

2. Mengakhiri kontrak dengan pihak yang gagal; atau

3. Meminta kepada pihak yang gagal untuk membayar ganti rugi atas setiap pengeluaran

\section{Kesimpulan}

Di Indonesia, gadai emas syariah menerapkan kombinasi dari tiga akad, yakni qard, rahn dan ijarah. Dalam praktiknya, perbankan syariah di Indonesia menerapkan beberapa item yang menyelisihhi syariah. Biaya (ujroh) atas sewa yang dikenakan kepada nasabah masih terkandung biaya yang tidak nyata-nyata diperlukan. Di Indonesia saat ini ada enam BUS yang menawarkan produk gadai emas syariah, yakni Bank Syariah Mandiri, BRI Syariah, BTPN Syariah, BJB Syariah, Bank Syariah Bukopin dan Bank Aceh.

Setidaknya ada empat fatwan DSN-MUI yang berhubungan dengan transaksi gadai emas syariah ini, yakni Fatwa DSN Nomor: 26/DSN-MUI/III/2002 tentang rahn emas, Fatwa DSN Nomor: 25/DSN-MUI/III/2002 tentang rahn, Fatwa DSN Nomor: 19/DSN-MUI/IV/2001 tentang al-qard, dan Fatwa DSN Nomor: 79/DSN-MUI/III/2011 tentang qardh dengan menggunakan dana nasabah.

Evaluasi kombinasi akad dari gadai emas syariah di Indonesia memerlukan perbaikan dan solusi agar bisa sesuai dengan ketentuan syariah. Penggabungan akad qard dan ijara tidak diperbolehkan berdasarkan hadits Rasulullah saw. AAOIFI secara tegas juga melarang kombinasi akad ini. Sebuah tawaran akad yang sesuai prinsip syariah yang ditawarkan penulis adalah pertama kombinasi akad Rahn dan ijarah, kedua menggunakan akad musyarakah mutanaqishah (kombinasi akad musyarakah dan ijarah muthahiyah bit tamlik).

\section{Daftar Pustaka}

Accounting and Auditing Organization for Islamic Financial Institutions (AAOIFI). Sharia standards. Bahrain: Author, 2003-2004

182 "Implementasi Akad Musyarakah Mutanaqishah pada Pembiayaan Kepemilikan Rumah di Bank Muamalat Lumajang", Iqtishoduna (Vol. 5, No. 1, April 2015), 26

183 Divisi Pengembangan Produk dan Edukasi Departemen Perbankan Syariah Otoritas Jasa Keuangan, Standar Produk Perbankan Syariah Musyarakah Mutanaqishah, (Jakarta: Otoritas Jasa Keuangan, 2016), 132 
Antonio, Syafii. Bank Syariah Dari Teori ke Praktik. Jakarta: Penerbit Gema Insani, 2001.

Arbouna, Muhammed Burhan “A Possible Mechannism for Product Development in Islamic Banking and Finance", Thunderbird International Business Review, Vol. 49, No. 3 (2007).

Elisa Valenta Sari. Gadai Emas Meningkat Bank Syariah Mandiri Bukukan Rp. 1,7 T. http:// www.cnnindonesia.com/ekonomi/20160614192719-78-138160/gadai-emas-meningkatbank-syariah-mandiri-bukukan-rp17-t/ (diakses 1 Januari 2017)

Fatwa DSN Nomor: 19/DSN-MUI/IV/2001 tentang Al-Qard

Fatwa DSN Nomor: 25/DSN-MUI/III/2002 tentang Rahn

Fatwa DSN Nomor: 26/DSN-MUI/III/2002 tentang Rahn Emas

Fatwa DSN Nomor: 79/DSN-MUI/III/2011 tentang Qardh dengan Menggunakan Dana Nasabah

Hammad. Ijtima' al-uqud al-Muta'didah fi Safaqah Wahida fi al-Fiqh al-Islami. A'mal alNadwah al-Fiqhiyyah al-Khamisa. Kuwait: Kuwait Finance House, 1998.

Mihajat, M.Iman Sastra. "Hybrid Contract in Islamic Banking and Finance: A Proposed Shariah Principles and Parameters for Product Development". European Journal of Business and Management-Special Issue: Islamic Management and Business. Vol. 7, No. 16 (2015)

Nurhayati, Sri. Akuntansi Syariah di Indonesia Edisi Empat. Jakarta: Salemba Empat, 2015

Putri Kamilatur Rohmi. "Implementasi Akad Musyarakah Mutanaqishah pada Pembiayaan Kepemilikan Rumah di Bank Muamalat Lumajang” Iqtishoduna, Vol. 5, No. 1 (2015)

Siregar, Mulya. Mencermati Rahn Emas pada Bank Syariah. http://zonaekis.com/mencermatirahn-emas-pada-bank-syariah/. (diakses pada 30 Desember 2016)

Otoritas Jasa Keuangan. Standar Produk Perbankan Syariah Musyarakah Mutanaqishah. Jakarta: Divisi Pengembangan Produk dan Edukasi Departemen Perbankan Syariah Otoritas Jasa Keuangan, 2016

Statistik Bank Indonesia 2012

Sudarsono, Heri. Bank dan Lembaga Keuangan Syariah: Deskripsi dan Ilustrasi. Yogyakarta: Ekonosia, 2003.

Tarmizi, Erwandi. Harta Haram Muamalat Kontemporer. Bogor: Penerbit Berkah Mulia Insani Publishing, 2013.

Undang-Undang Nomor 21 tahun 2008 tentang perbankan syariah 